\title{
Induction of Chalcone Synthase Expression by Rhizobia and Nod factors in Root Hairs and Roots
}

\author{
Andrea Krause, Vo T. T. Lan, and William J. Broughton \\ L. B. M. P. S., Université de Genève, 1, ch. de l'Impératrice, 1292 Chambésy, Genève, Switzerland \\ Received 21 June 1996. Accepted 14 January 1997.
}

\begin{abstract}
Chalcone synthase (CHS) of Vigna unguiculata is encoded by a gene family that is abundantly transcribed in leaves and nodules. Inoculation with Rhizobium sp. NGR234, which nodulates $V$. unguiculata, or with NGR $\triangle$ nodABC, a mutant deficient in Nod factor production, induced rapid accumulation of CHS mRNAs in roots and root hairs. As both $\mathrm{Nod}^{+}$and $\mathrm{Nod}^{-}$bacteria provoke responses, induction of CHS gene expression may involve symbiotic or defense responses. Four days after inoculation with the wild-type Rhizobium sp., the transcript levels increased in roots but decreased in root hairs. Use of a region unique to the $5^{\prime}$ end of a specific CHS gene (VuCHS1) showed that increases of transcript levels in root hairs $24 \mathrm{~h}$ after inoculation with both rhizobia were specific to this gene. Transcripts of this gene in roots were only detectable 4 days after treatment with NGR234. It is possible therefore that accumulation of VuCHS1 follows the infection pathway of rhizobia entering legume roots. Purified Nod factors induced accumulation of transcripts, showing that they might be part of the signal transduction pathway leading to CHS expression.
\end{abstract}

Additional keyword: symbiosis.

Nitrogen-fixing nodules develop on the roots of legumes as a result of infection by symbiotic rhizobia. The interaction begins when rhizobia are attracted to root hairs by plantsecreted flavonoids, signal molecules that induce rhizobial nod genes (Fellay et al. 1995). Induction of nod genes results in the synthesis and excretion of Nod factors, the bacterial signals in the molecular conversation between the two symbiotic partners (Schultze et al. 1994). To penetrate the host root, rhizobia cause a reorientation of root hair cell growth, resulting in deformed and curled root hairs (Bauer 1981). Within these curled root hairs, the invading bacteria promote the formation of infection threads, through which they are conducted toward the root. Simultaneously, rhizobia induce the development of pre-meristems in the root cortex, the nodule primordia. Once the infection thread reaches the primordium, the symbiotic bacteria are released into the plant cytoplasm (Robertson et al. 1978). This leads to the development of a completely new plant organ-the nodule-in which the bacteria

Corresponding author: Andrea Krause; Tel: 41-22-7320420; Fax: 41-227320734; E-mail: Krause@sc2a.unige.ch

Nucleotide sequence data are to be found at the EMBL, GenBank, and DDBJ data bases as accession number X74821. fix atmospheric nitrogen (Mylona et al. 1995). As rhizobia interact first with root hairs and then with roots, the molecular responses of plants must follow the infection pathway.

Vigna unguiculata is a popular and important source of protein in human diets. It is widely cultivated, especially in Africa, India, and North America. It has been proposed as a model plant in studies of Rhizobium-legume interactions (Krause et al. 1994) and was chosen for the analysis of early plant responses to infection.

Chalcone synthase (CHS) is an enzyme of central importance in the biosynthetic pathway of all classes of flavonoids (Hahlbrock and Scheel 1989). It catalyzes the stepwise condensation of three acetate residues from malonyl CoA with 4coumaroyl CoA to naringenin-chalcone (Heller and Halbrock 1980). CHS expression is under complex tissue-specific and developmental regulation. Environmental stimuli, including wounding, interaction with microorganisms, light, nutrient supplies, e.g., nitrogen (Coronado et al. 1995), and plant hormones all affect CHS expression (Dixon and Harrison 1990; Hahlbrock and Scheel 1989). In Rhizobium-legume interactions, CHS expression is enhanced during different stages of nodule development (Coronado et al. 1995). Extensive studies with Glycine max have shown that inoculation with nodulating Bradyrhizobium rapidly induces expression of specific members of the chs gene family (Estabrook and Sengupta-Gopalan 1991). This de novo synthesis of CHS is in accordance with flavonoid accumulation observed in root exudates following inoculation (Schmidt et al. 1994). Rhizobium leguminosarum bv. trifolii induces CHS expression in the roots of Trifolium subterraneum before bacterial penetration begins (Lawson et al. 1994). Rhizobial infection of G. max also influences CHS expression during the later stages of nodule development (Wingender et al. 1989). Highest levels of CHS expression occur in noninfected parts of Pisum sativum nodules, suggesting a role in development of the nodule structure (Yang et al. 1992). CHS is therefore an excellent marker gene to follow the spatial and temporal effects in legumes of rhizobial infection.

\section{RESULTS}

Isolation of cDNAs encoding chalcone synthase.

Three of $1 \times 10^{5}$ recombinant phages isolated from a root hair cDNA library synthesized from mRNA (extracted 1 and 4 days after inoculation with rhizobia in a 9:1 ratio; Krause et al. 1994) hybridized to CHS of Antirrhinum majus. All three clones carried an insert of approximately the same size. Terminal sequence analysis showed that they are identical. The 
1,415-bp sequence of one clone (VuCHS1) was completed. It contains an open reading frame of 388 amino acids (Fig. 1). A search of nucleic acid and protein data bases revealed high sequence similarity to chs genes of other legumes (Table 1). Homology starts at the first methionine and continues throughout the open reading frame. In agreement with the data of Estabrook and Sengupta-Gopalan (1991), these similarities dramatically declined when the $5^{\prime}$ and $3^{\prime}$ untranslated regions were compared.

\section{Genomic organization.}

To determine the number of genes encoding for CHS in $V$. unguiculata, genomic DNA was digested with various restriction enzymes, and Southern transfer analysis was performed with the entire VuCHS1 or the $5^{\prime}$ end of VuCHS1 as probe. The entire VuCHS1 gave multiple hybridization signals for each restriction digest, indicating that numerous loci in the genome of $V$. unguiculata encode CHS (Fig. 2). Under high stringency conditions, the $5^{\prime}$ end hybridized strongly to a single band, confirming that VuCHS1 represents one member of the CHS family (Fig. 2). Thus, the $5^{\prime}$ end of VuCHS1 can be used as a gene-specific probe.

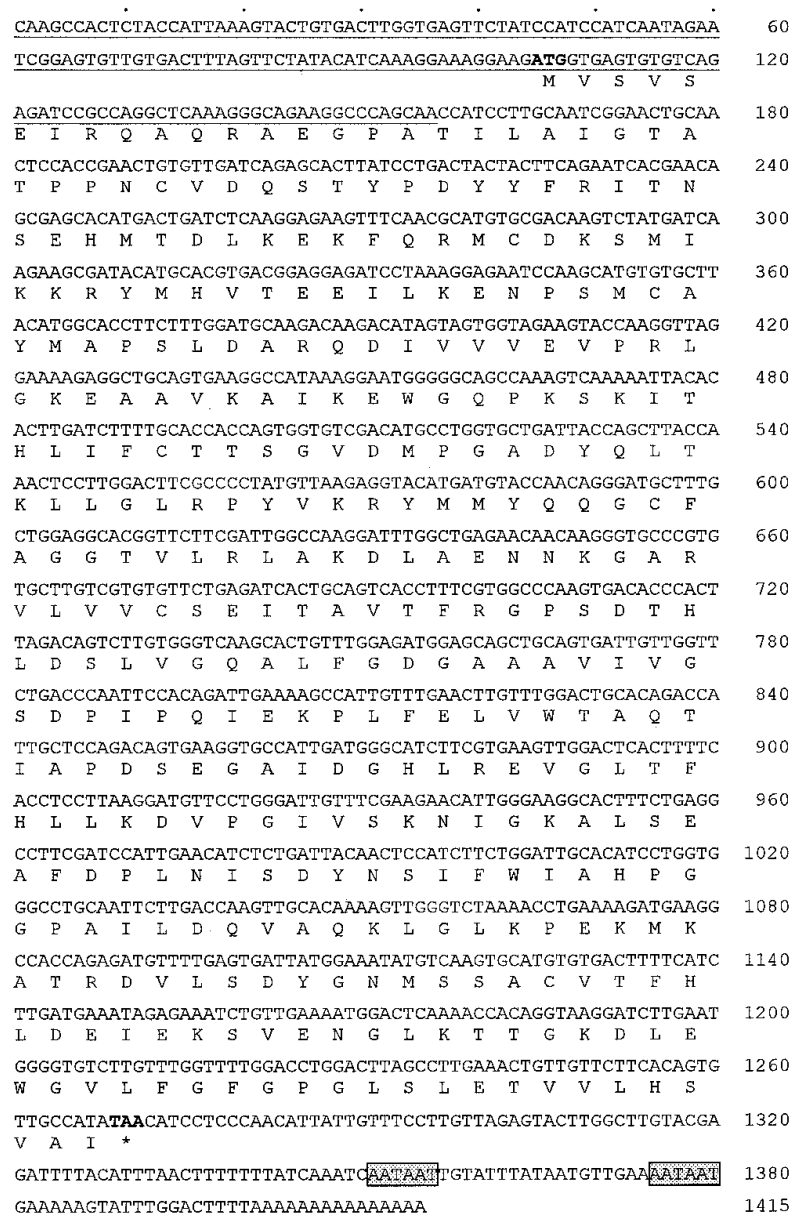

Fig. 1. Nucleotide and predicted amino acid sequence of the EcoRI fragment of pVuCHS1. The start and stop codons of the open reading frame are marked in bold; the $5^{\prime}$ part used to synthesize a gene-specific probe is underlined. The two putative adenylation signals are boxed.
Tissue-specific expression of CHS in V. unguiculata.

Northern (RNA) blot analysis with total RNA extracted from different tissues was used to study tissue-specific expression. The entire VuCHS1 hybridized to a transcript of 1,500 nucleotides in several organs, suggesting that VuCHS1 is a full-length cDNA clone. Highest levels of CHS transcripts were visible in nodules and pseudo-nodules formed by the Fix mutant NGR $\Delta$ fixF (Fig. 3). Lower levels of transcripts were visible in leaves (Fig. 3). In over-exposed autoradiograms, weak hybridization signals were found with RNA extracted from young roots, root hairs, and young flower buds, indicating that low amounts of transcripts are present in these tissues (data not shown).

Table 1. Similarity of VuCHS1 to $c h s$ genes of other legumes

\begin{tabular}{lcccc}
\hline & & \multicolumn{2}{c}{ Identity (level) } & \\
\cline { 2 - 4 } Plant & Clone & $\begin{array}{c}\text { DNA } \\
\text { Deduced } \\
\text { protein }\end{array}$ & $\begin{array}{c}\text { (\%) } \\
\text { (\%) }\end{array}$ & Reference \\
\hline Glycine max & Gmchs7 & 87 & 92 & Akada et al. 1993 \\
Medicago sativa & Mschs9 & 80 & 90 & Junghans et al. 1993 \\
Phaseolus vulgaris & Pvchalcsn & 87 & 95 & Ryder et al. 1987 \\
Pisum sativum & Pschs3 & 78 & 90 & Ichinose et al. 1992 \\
Pueraria lobata & Plchs & 83 & 93 & Nakajima et al. 1991 \\
Trifolium subterraneum & Tschs5 & 80 & 90 & Howles et al. 1995 \\
\hline
\end{tabular}

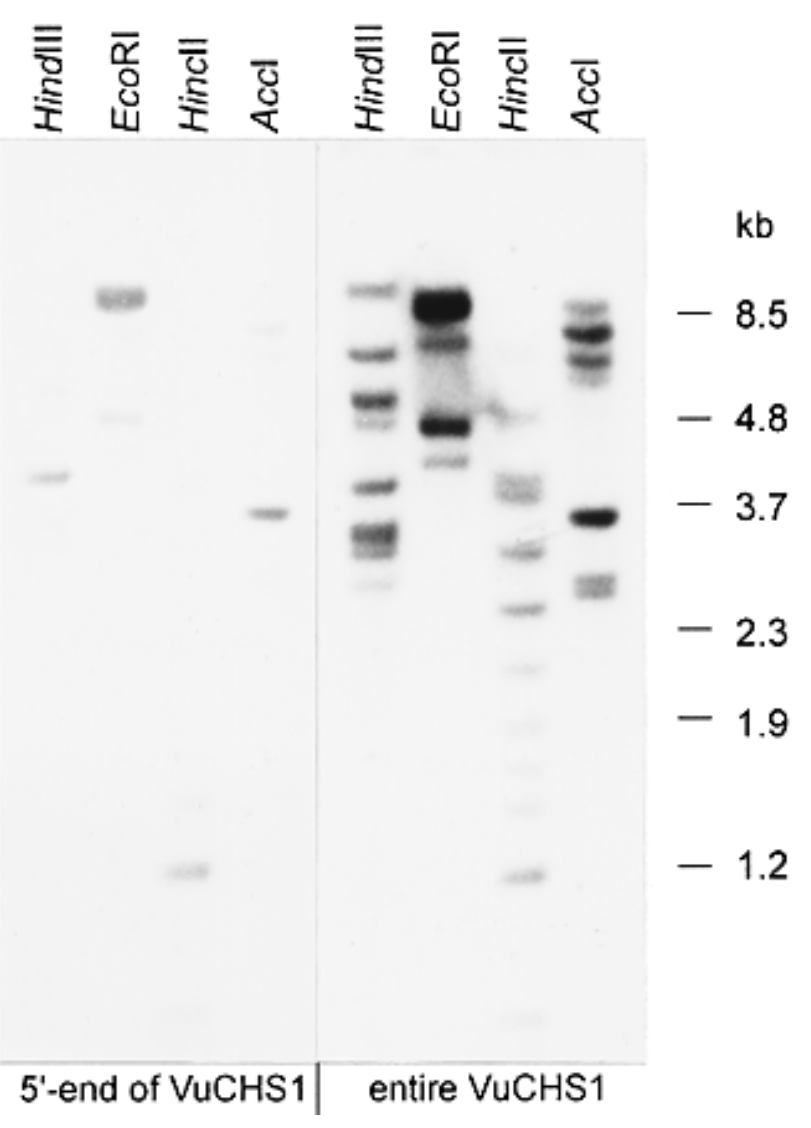

Fig. 2. Southern blot hybridization of total DNA from Vigna unguiculata $(10 \mu \mathrm{g}$ per lane) digested with various enzymes and probed against the gene-specific 5' end of VuCHS1 and the entire VuCHS1. 


\section{Differential expression of CHS during the early stages of nodule development.}

The spatial distribution and temporal accumulation of CHS expression during binding of rhizobia to root hairs and during root hair deformation/curling were analyzed in root hairs and roots. Through analysis of root hairs separately, CHS activities in the early symbiotic stages will be enriched and thus lower amounts of mRNAs can be detected. At first, the entire VuCHS1 was used as probe. In root hairs (Fig. 4A), highest levels of CHS mRNA were found $24 \mathrm{~h}$ after treatment with NGR $\triangle \operatorname{nod} A B C$, a mutant that is unable to produce Nod factors and thus fails to induce nodules (Relić et al. 1993a, 1994). Rhizobium sp. NGR234, which nodulates V. unguiculata, induced less pronounced accumulation of CHS mRNA (Fig. 4A). Four days after inoculation with NGR234, CHS mRNAs were no longer detectable in root hairs. Transcripts were still visible following treatment with NGR $\triangle \operatorname{nod} A B C$, although the amount of transcripts was drastically reduced, compared with day 1 (Fig. 4A). In roots, the NGR $\triangle$ nod $A B C$ mutant induced increases (in $\leq 24 \mathrm{~h}$ ) in CHS transcript levels of only $24 \%$ of those found following inoculation with NGR234 (Fig 5A). This level remained unchanged through day 4. Treatment with the wild-type Rhizobium sp. increased the amount of transcripts by day 4 (Fig. 5A). Thus, the kinetics of CHS transcript accumulation varies with the inoculant and the tissue.

To determine whether rhizobia-induced expression of CHS is confined to VuCHS1, the gene-specific $5^{\prime}$ end was used as a probe in Northern analysis. Twenty-four hours after inoculation with both rhizobia, a pattern similar to that described above was visible in root hairs (Fig. 4B). Four days after inoculation, the level of VuCHS1 mRNAs declined to control levels in both treatments. This suggests that in root hairs VuCHS1 is the only active transcript CHS gene (Fig. 4A,B). In roots, increased amounts of these specific transcripts were only detected 4 days after inoculation with NGR234 and they were not seen following treatment with the Nod mutant (Fig. 5B). Thus, other genes encoding CHS are active early in the infection process while VuCHS1 is expressed later (compare Figure 5A and B).

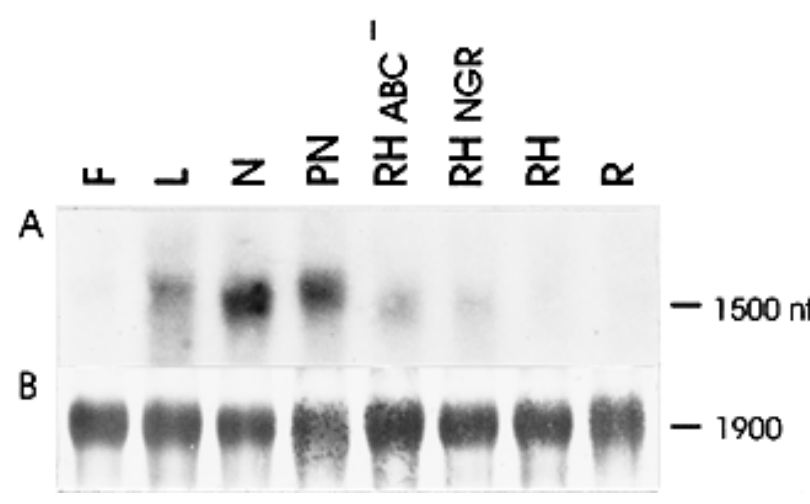

Fig. 3. Expression of a gene-encoding chalcone synthase of Vigna unguiculata in different tissues and in response to inoculation with Rhizobium. Total RNA (10 $\mu \mathrm{g}$ per lane) was extracted from flower buds $(\mathrm{F})$, young leaves $(\mathrm{L})$, nodules $(\mathrm{N})$, and pseudo-nodules (PN) harvested 5 weeks after inoculation, root hairs harvested $24 \mathrm{~h}$ after treatment with Rhizobium sp. NGRAnodABC (RH ABC ${ }^{-}$), with Rhizobium sp. NGR234 (RH NGR), or with sterile water $(\mathrm{RH})$, and from 4-day-old untreated roots (R). (A) Hybridization with the entire insert of pVuCHS1 as probe. (B) Ribosomal RNA detected by staining the filter with methylene blue.

\section{Effect of purified Nod factors on CHS expression.}

Rhizobia synthesize and excrete specific molecules (Nod factors) that are essential for root hair deformation, root hair curling, and nodule development. An obvious question therefore is whether CHS expression in root hairs can also be induced by Nod factors. Root hairs were sprayed with purified, acetylated Nod factors at concentrations that cause root hair deformation and curling. With the gene-specific $5^{\prime}$ end as probe it is obvious that Nod factors stimulate VuCHS1 expression 1 day after treatment (Fig. 6). Transcript levels were dependent on Nod factor concentration with a maximum at $10^{-6} \mathrm{M}$, indicating that Nod factors are signals involved in modulating CHS expression.

\section{DISCUSSION}

CHS is encoded by a multi-gene family in which each member is differently regulated by various signals (Harker et al. 1990; Lawson et al. 1994). In V. unguiculata, high levels of CHS transcripts were observed in nodules and to a lesser extent in leaves. Only very low amounts of transcripts were detected in flowers, which is in agreement with the observations of Schmid et al. (1990) for Phaseolus vulgaris and Harker et al. (1990) for Pisum sativa. Low amounts of transcripts in roots of $V$. unguiculata contrast with the situation in G. max (Estabrook and Sengupta-Gopalan 1991) and Medicago sativa (McKhann and Hirsch 1994; Sallaud et al. 1995), where they predominate. Junghans et al. (1993) observed that CHS transcript levels were much lower in young roots of petri-dishgrown plants than in mature roots from 8- to 10 -week-old greenhouse-grown plants. This might explain the low levels of CHS mRNA observed in $V$. unguiculata.

Induction of CHS expression in roots as an early response to inoculation with Rhizobium spp. has been described for $G$. max (Estabrook and Sengupta-Gopalan 1991), M. sativa (Coronado et al. 1995), T. subterraneum (Lawson et al. 1994),

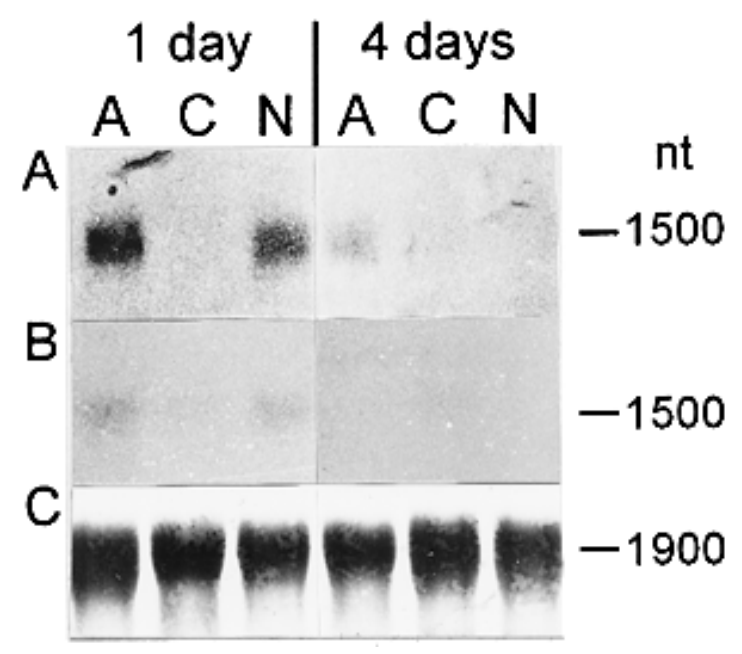

Fig. 4. Differential expression of chalcone synthase in root hairs of $\mathrm{Vi}$ gna unguiculata following treatment with rhizobia. Ten micrograms of total RNA was used for Northern (RNA) blot analysis. RNA was isolated from untreated root hairs (C), or root hairs treated with Rhizobium sp. NGR234 (N) or NGR $\Delta$ nodABC (A) 1 day and 4 days after inoculation. Hybridization with (A) the entire VuCHS1 as probe or (B) the genespecific $5^{\prime}$ end of VuCHS1. (C) Filter stained with methylene blue. 
and Vicia sativa (Recourt et al. 1992), but, to the best of our knowledge, similar studies have not been made on root hairs. In V. unguiculata, VuCHS 1 is a variant of the chs gene family induced early in the symbiosis. The NGR234-stimulated induction of VuCHS1 expression was measurable $24 \mathrm{~h}$ after treatment in root hairs, but not in roots. Transcript levels decrease in root hairs but increase in roots 4 days after inoculation. It seems as if high levels of VuCHS1 transcripts follow the invasion process that begins with rhizobial attachment to root hairs and ends with bacteroid release into cortical cells. This hypothesis is supported by microscopic observation of the infection process, which shows that root hair involvement diminishes 4 days after inoculation (Krause and Broughton 1992), and by the results of Schmidt et al. (1994), who postulated a physiological link between meristem induction and flavonoid accumulation.

With the entire CHS as probe, transcripts were detectable in roots after treatment with NGR234, indicating that expression of additional CHS genes can be activated within $24 \mathrm{~h}$ by nodulating rhizobia. Whether activation of other CHS genes is part of a defense reaction of the plant against the symbiotic bacteria, or if the process of nodule development benefits from this, remains unclear.

The $\operatorname{nod} A B C$ mutant also induces rapid accumulation of VuCHS1 mRNAs in root hairs. Estabrook and SenguptaGopalan (1991) showed that heterologous, non-nodulating $R$. meliloti caused a general induction of CHS gene expression in G. max. Perhaps this indicates that a non-nodulating Rhizobium mutant might trigger plant defense responses (Grosskopf et al. 1993). Induction of CHS genes involved in plant defense by non-nodulating rhizobia thus seems probable. Therefore, VuCHS 1 expression might be induced by two mechanisms, a nodulation-specific one and one related to defense. In roots, levels of CHS transcripts did not change with the time after inoculation with NGR $\triangle \operatorname{nod} A B C$, indicating that expression does not proceed further in the absence of nodule-forming bacteria and suggesting that the infection process is aborted.

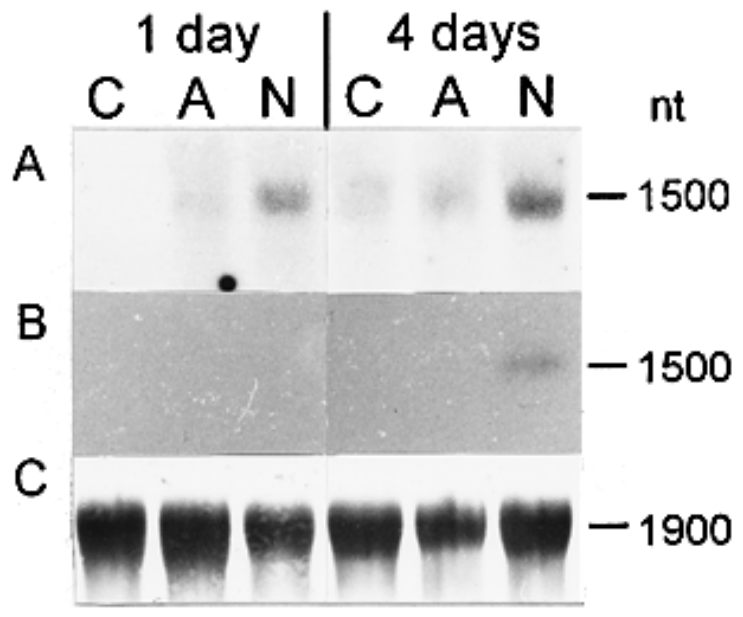

Fig. 5. Determination of transcript levels encoding chalcone synthase in roots of Vigna unguiculata. For Northern (RNA) blot analysis, $10 \mu \mathrm{g}$ of total RNA was extracted 1 day and 4 days after inoculation from untreated roots (C), or roots treated with Rhizobium sp. NGR234 (N) or with the nodABC mutant (A). Hybridization with (A) the entire VuCHS1 as probe or the (B) gene-specific $5^{\prime}$ end of VuCHS1. (C) Filter stained with methylene blue.
Nod factor-induced accumulation of VuCHS1 transcripts in root hairs is in accordance with the data of Schmidt et al. (1994), who showed that acetylated NodNGR factors enhance flavonoid accumulation in roots of G. max. Our data contrast with the observations of Lawson et al. (1994), however, who were unable to detect any influence of crude Nod factor preparations (that induced root hair curling) on CHS expression in T. subterraneum. Factors inhibiting plant gene expression could be present in these crude preparations and thus induction of CHS gene expression might fail. In any event, it seems likely that Nod factors are part of the signal transduction pathway that leads to increased CHS expression during establishment of symbiotic interactions.

One possible function of CHS in symbioses is the synthesis of new flavonoids that might act as endogenous, auxintransport inhibitors (Jacobs and Rubery 1988), thereby perturbing the endogenous hormone balance. Shifts in the auxincytokinin balance have been shown to induce the formation of nodule-like structures (Relić et al. 1993a, 1993b). To function in this manner, flavonoids that are produced as a result of Rhizobium-stimulated expression of CHS must be synthesized early in the interaction. In our system, activation of the CHS expression correlates with the onset of root hair deformation: this is early enough to be involved in induction of cortical cell division and nodule development.

\section{MATERIALS AND METHODS}

\section{Bacterial and plant material.}

Escherichia coli strains, plasmids, and bacteriophages were grown as described by Sambrook et al. (1989). Rhizobium strains were cultivated in TY medium and prepared as inoculum as described by Krause and Broughton (1992). Acetylated Nod factors were isolated from apigenin-induced, large-scale cultures of the overproducing strain NGR234(p28) and purified on a $\mathrm{C}_{18}$ reverse-phase high-pressure liquid chromatogra-

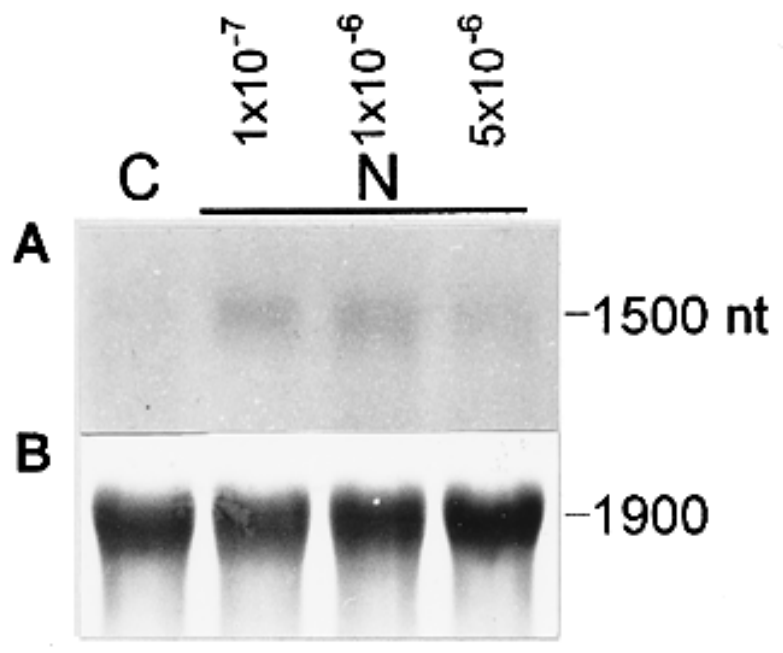

Fig. 6. Changes in transcript levels of VuCHS1 induced by purified, acetylated Nod factors. Root hairs were isolated from seedlings 1 day after treatment with acteylated NodNGR-factors $\left[10^{-7}, 10^{-6}\right.$, and $5 \times 10^{-6}$ $\mathrm{M}]$. As a control, sterile water was sprayed on seedlings. (A) Northern (RNA) blot hybridization against $10 \mu \mathrm{g}$ of total RNA extracted with the gene-specific 5' end of VuCHS1 as probe. (B) Amounts of ribosomal RNA obtained by staining the same filter with methylene blue. 
phy column (Price et al. 1992). A stock solution of purified, acetylated Nod factor [NodNGR-V(Carb $1, N M e, C 18: 1)$ (MeFuc, Ac) and NodNGR-V(Carb $2, N \mathrm{Me}, \mathrm{C} 18: 1)(\mathrm{MeFuc}$, Ac)] was diluted in sterile water to $10^{-7}, 10^{-6}$, or $5 \times 10^{-6} \mathrm{M}$. Seeds of Vigna unguiculata (L.) Walp. 'Red Caloona' were obtained from Rawling Seeds (Orpington, Kent, Great Britain). Seeds were surface sterilized and germinated as described by Krause and Broughton (1992). Two days later, bacterial inoculum or Nod factors $(1 \mathrm{ml}$ per 50 plants) were sprayed on the seedlings, and cultivated further (Krause et al. 1994). As a control, seedlings were treated with sterile water. To extract RNA, root hairs were stripped from roots 1 day and 4 days after inoculation, following the method of Röhm and Werner (1987). Young leaves, flower buds, and 5-week-old nodules were harvested from plants inoculated with Rhizobium sp. NGR234. Pseudo-nodules were collected 5 weeks after inoculation of seedlings with the Fix mutant, NGR $\Delta$ fix $F$ (B. Relić and W. J. Broughton, unpublished). Roots of 4-dayold, uninoculated seedlings were separated from root hairs; RNA was prepared from both fractions.

\section{Isolation of a Vigna unguiculata chs cDNA clone.}

Approximately $1 \times 10^{5}$ recombinant phages of a cDNA library constructed from poly $(\mathrm{A})^{+} \mathrm{RNA}$ of $V$. unguiculata root hairs treated with NGR234 (Krause et al. 1994) were screened with a 1.2-kb PstI cDNA (cA1) clone encoding CHS in Antirrhinum majus (Sommer and Saedler 1986). Hybridization with the randomly labeled cA1 fragment was performed overnight at $62^{\circ} \mathrm{C}$ in $3 \times \mathrm{SSC}(1 \times \mathrm{SSC}$ is $0.15 \mathrm{M} \mathrm{NaCl}$ plus $0.015 \mathrm{M}$ sodium citrate), $0.02 \%$ (wt/vol) Ficoll, $0.02 \%$ (wt/vol) polyvinylpyrrolidone, and $0.1 \%(\mathrm{wt} / \mathrm{vol})$ sodium dodecyl sulfate (SDS), containing herring sperm DNA $\left(100 \mu \mathrm{g} \mathrm{m}^{-1}\right)$ (Sambrook et al. 1989). Filters were washed at $62^{\circ} \mathrm{C}$ twice in $2 \times \mathrm{SSC}$ and $0.1 \%$ (wt/vol) SDS for $10 \mathrm{~min}$ and once in $0.1 \times \mathrm{SSC}$ and $0.1 \%$ (wt/vol) SDS. Appropriate inserts were re-cloned into the EcoRI site of the pBluescript II SK(+) vector (Stratagene, La Jolla, CA). The DNA sequence of exonuclease III-derived clones (Henikoff 1987) was determined with the dideoxy chain termination method (Sequenase II, USB, Cleveland, OH). DNA sequence data were analyzed with PC/Gene (IntelliGenetics Inc. Mountain View, CA) and the Blast network service (National Center for Biotechnology Information, Bethesda, MA; Altschul et al. 1990; Gish and States 1993).

\section{DNA and RNA extraction and analysis.}

Genomic DNA of $V$. unguiculata was isolated as described by Schwarz-Sommer et al. (1984). All other recombinant DNA methods, including Southern blot analysis, were performed according to Sambrook et al. (1989).

Total plant RNA for Northern blot analysis was extracted as described by Chandler et al. (1983). After separation of $10 \mu \mathrm{g}$ of total RNA on denaturing agarose gels and transfer to nylon membranes, the amount and the integrity of ribosomal RNA was confirmed by staining the filters with methylene blue (Sambrook et al. 1989). The stained filters were subsequently analyzed densitometrically (QuantiScan, Biosoft, Cambridge, Great Britain) to confirm equal loading.

For Northern and Southern blots, hybridizations were performed at $42^{\circ} \mathrm{C}$, in the presence of $50 \%$ formamide (Sambrook et al. 1989). Washing was done twice at $65^{\circ} \mathrm{C}$ with $0.1 \times$ $\mathrm{SSC}, 0.1 \%$ (wt/vol) SDS for $15 \mathrm{~min}$.
Probes were generated by random labeling (Sambrook et al. 1989) for the entire VuCHS1 fragment or by polymerase chain reaction for the gene-specific $5^{\prime}$ end that was obtained by exonuclease III digestion. A standard protocol for labeling by polymerase chain reaction with $\left[\alpha^{32} \mathrm{P}\right] \mathrm{dCTP}$ was applied (Sambrook et al. 1989).

\section{ACKNOWLEDGMENTS}

We are grateful to $\mathrm{H}$. Sommer for making the chalcone synthase cDNA clone of Antirrhinum majus available and to B. Relic for the NGR $\Delta$ fixF mutant. S. Relić and F. Talmont provided the NodNGR factors. We thank I. Arsenijević-Maksimović, K. Seidel, M. Shayya, and R. Vögeli-Lange for critical reading of the manuscript. The second author was the recipient of a fellowship from the Commission Fédérale des Bourses pour Etudiants Etrangers. This study was supported by the University of Geneva, the Roche Research Foundation, and the Fonds National Suisse de la Récherche Scientifique (Projects 31-30950.91 and 31-40714.94).

\section{LITERATURE CITED}

Akada, S., Kung, S., and Dube, S. 1993. Nucleotide sequence and putative regulatory elements of a nodule-development-specific member of the soybean (Glycine max) chalcone synthase multigene family, Gmchs7. Plant Physiol. 102:321-323.

Altschul, S. F., Gish, W., Miller, W., Myers, E. W., and Liptman, D. J. 1990. Basic local alignment search tool. J. Mol. Biol. 215:403-410.

Bauer, W. D. 1981. Infection of legumes by rhizobia. Annu. Rev. Plant Physiol. 32:407-449.

Chandler, P. M., Higgins, T. J. V., Randall, P. J., and Spencer, D. 1983. Regulation of legumin levels in developing pea seeds under conditions of sulfur deficiency. Plant Physiol. 71:47-54.

Coronado, C., Zuanazzi, J. A. S., Sallaud, C., Quirion, J.-C., Esnault, R., Husson, H.-P., Kondorosi, A., and Ratet, P. 1995. Alfalfa root flavonoid production is nitrogen regulated. Plant Physiol. 108:533-542.

Dixon, R. A., and Harrison, M. J. 1990. Activation, structure and organization of genes involved in microbial defense in plants. Adv. Genet. 28:165-234.

Estabrook, E. M., and Sengupta-Gopalan, C. 1991. Differential expression of phenylalanine ammonia-lyase and chalcone synthase during soybean nodule development. Plant Cell 3:299-308.

Fellay, R., Rochepeau, P., Relić, B., and Broughton, W. J. 1995. Signals to and emanating from Rhizobium largely control symbiotic specificity. Pages 199-220 in: Pathogenesis and Host Specificity in Plant Diseases. Histopathological, Biochemical, Genetic and Molecular Bases. Vol. 1: Prokaryotes. U. S. Singh, R. P. Singh, and K. Kohmoto, eds. Pergamon/Elsevier Science, Oxford.

Gish, W., and States, D. J. 1993. Identification of protein coding regions by database similarity search. Nat. Genet. 3:89-98.

Grosskopf, E., Ha, D. T. C., Wingender, R., Röhrig, H., Szecsi, J., Kondorosi, E., Schell, J., and Kondorosi, A. 1993. Enhanced levels of chalcone synthase in alfalfa nodules induced by a Fix ${ }^{-}$mutant of Rhizobium meliloti. Mol. Plant-Microbe Interact. 6:173-181.

Hahlbrock, K., and Scheel, D. 1989. Physiology and molecular biology of phenylpropanoid metabolism. Annu. Rev. Plant Physiol. Plant Mol. Biol. 40:347-369.

Harker, C. L., Ellis, T. H. N., and Coen, E. S. 1990. Identification and genetic regulation of the chalcone synthase multigene family in pea. Plant Cell 2:185-194.

Heller, W., and Halbrock, K. 1980. Highly purified flavanone synthase from parsley catalyzes the formation of naringenin chalcone. Arch. Biochem. Biophys. 200:617-619.

Henikoff, S. 1987. Unidirectional digestion with exonuclease III in DNA sequence analysis. Methods Enzymol. 155:156-167.

Howles, P. A., Arioli, T., and Weinman, J. J. 1995. Nucleotide sequence of additional members of the gene family encoding chalcone synthase in Trifolium subterraneum. EMBL Data Libr. Rel. 42, Access. No. L24517.

Ichinose, Y., Kawamata, S., Yamada, T., An, C., Kajiwara, T., Shiraishi, T., and Oku, H. 1992. Molecular cloning of chalcone synthase cDNA 
from Pisum sativum. Plant Mol. Biol. 18:1009-1012.

Jacobs, M., and Rubery, P. H. 1988. Naturally occurring auxin transport regulators. Science 241:346-349.

Junghans, H., Dalkin, K., and Dixon, R. A. 1993. Stress responses in alfalfa (Medicago sativa L.). 15. Characterization and expression patterns of members of a subset of the chalcone synthase multigene family. Plant Mol. Biol. 22:239-253.

Krause, A., and Broughton, W. J. 1992. Proteins associated with roothair deformation and nodule initiation in Vigna unguiculata. Mol. Plant-Microbe Interact. 5:96-103.

Krause, A., Sigrist, C. J. A., Dehning, I., Sommer, H., and Broughton, W. J. 1994. Accumulation of transcripts encoding a lipid transfer-like protein during deformation of nodulation-competent Vigna unguiculata root hairs. Mol. Plant-Microbe Interact. 7:411-418.

Lawson, C. G. R., Djordjevic, M. A., Weinman, J. J., and Rolfe, B. G. 1994. Rhizobium inoculation and physical wounding result in the rapid induction of the same chalcone synthase copy in Trifolium subterraneum. Mol. Plant-Microbe Interact. 7:498-507.

McKhann, H. I., and Hirsch, A. M. 1994. Isolation of chalcone synthase and chalcone isomerase cDNAs from alfalfa (Medicago sativa L.): highest transcript levels occur in young roots and root tips. Plant Mol. Biol. 24:767-777.

Mylona, P., Pawlowski, K., and Bisseling, T. 1995. Symbiotic nitrogen fixation. Plant Cell 7:869-885

Nakajima, O., Akiyama, T., Hakamatsuka, T., Shibuya, M., Noguchi, H., Ebizuka, Y., and Sankawa, U. 1991. Isolation, sequencing and bacterial expression of a cDNA for chalcone synthase from the cultured cells of Pueraria lobata. Chem. Pharm. Bull. 39:1911-1913.

Price, N. P. J., Relić, B., Talmont, F., Lewin, A., Promé, D., Pueppke, S. G., Maillet, F., Dénarié, J., Promé, J.-C., and Broughton, W. J. 1992. Broad-host-range Rhizobium species strain NGR234 secretes a family of carbamoylated, and fucosylated, nodulation signals that are $O$ acetylated or sulphated. Mol. Microbiol. 6:3575-3584.

Recourt, K., van Tunen, A. J., Mur, L. A., van Brussel, A. A. N. Lugtenberg, B. J. J., and Kijne, J. W. 1992. Activation of flavonoid biosynthesis in roots of Vicia sativa subsp. nigra plants by inoculation with Rhizobium leguminosarum biovar viciae. Plant Mol. Biol. 19: 411-420.

Relić, B., Fellay, R., Lewin, A., Perret, X., Price, N. P. J., Rochepeau, P., and Broughton, W. J. 1993a. nod genes and Nod factors of Rhizobium species NGR234. Pages 183-189 in: New Horizons in Nitrogen Fixation. R. Palacios, J. Mora, and W. E. Newton, eds. Kluwer Academic, Dordrecht, The Netherlands.

Relić, B., Talmont, F., Kopcinska, J., Golinowski, W., Promé, J.-C., and Broughton, W. J. 1993b. Biological activity of Rhizobium sp. NGR234 Nod-factors on Macroptilium atorpurpureum. Mol. PlantMicrobe Interact. 6:764-774.
Relić, B., Perret, X., Estrada-Garcia, M. T., Kopcinska, J., Golinowski, W., Krishnan, H. B., Pueppke, S. G., and Broughton, W. J. 1994. Nod factors of Rhizobium are a key to the legume door. Mol. Microbiol. 13:171-178.

Robertson, J. G., Lyttleton, P., Bullivan, S., and Grayston, G. F. 1978. Membranes in lupin root nodules. I. The role of Golgi bodies in the biogenesis of infection threads and peribacteroid membranes. J. Cell Sci. 30:129-149.

Röhm, M., and Werner, D. 1987. Isolation of root hairs from seedlings of Pisum sativum. Identification of root hair specific proteins by in situ labeling. Physiol. Plant. 69:129-136.

Ryder, T. B., Hedrick, S. A., Bell, J. N., Liang, X., Clouse, S. D., and Lamb, C. J. 1987. Organization and differential activation of a gene family encoding the plant defense enzyme chalcone synthase in Phaseolus vulgaris. Mol. Gen. Genet. 210:219-233.

Sallaud, C., El-Turk, J., Breda, C., Buffard, D., de Kozak, I., Esnault, R., and Kondorosi, A. 1995. Differential expression of cDNA coding for chalcone reductase, a key enzyme of the 5-deoxyflovonoid pathway, under various stress conditions in Medicago sativa. Plant Sci. 109:179-190

Sambrook, J., Fritsch, E. F., and Maniatis, T. A. 1989. Molecular Cloning: A Laboratory Manual. 2nd ed. Cold Spring Harbor Laboratory, Cold Spring Harbor, NY.

Schmid, J., Doerner, P. W., Clouse, S. D., Dixon, R. A., and Lamb, C. J. 1990. Developmental and environmental regulation of a bean chalcone synthase promoter in transgenic tobacco. Plant Cell 2:619-631.

Schmidt, P. E., Broughton, W. J., and Werner, D. 1994. Nod factors of Bradyrhizobium japonicum and Rhizobium sp. NGR234 induce flavonoid accumulation in soybean root exudate. Mol. Plant-Microbe Interact. 7:384-390.

Schultze, M., Kondorosi, E., Ratet, P., Buiré, M., and Kondorosi, A. 1994. Cell and molecular biology of Rhizobium-plant interactions. Int. Rev. Cytol. 156:1-75.

Schwarz-Sommer, Z., Gierl, A., Klösgen, R. B., Wienand, U., Peterson, P. A., and Saedler, H. 1984. The Spm (EN) transposable element controls the excision of a 2-kb insert at the wx-m8 allele of Zea mays. EMBO J. 3:1021-1028.

Sommer, H., and Saedler, H. 1986. Structure of the chalcone synthase gene of Antirrhinum majus. Mol. Gen. Genet. 202:429-434.

Wingender, R., Röhrig, H., Höricke, C., Wing, D., and Schell, J. 1989. Differential regulation of soybean chalcone synthase genes in plant defence, symbiosis and upon environmental stimuli. Mol. Gen. Genet. 218:315-322

Yang, W.-C., Canter Cremers, H. C. J., Hogendijk, P., Katinakis, P., Wijffelman, C. A., Franssen, H., van Kammen, A., and Bisseling, T. 1992. In-situ localization of chalcone synthase mRNA in pea root nodule development. Plant J. 2:143-152. 